\title{
Contributions of Community Stakeholders in the Co-production of Female Child Education in Nigeria
}

\author{
Mansur Muhammad Bello \\ Department of Public Administration, Faculty of Management and Social Sciences, \\ Federal University Gusau, Zamfara State
}

Bilyaminu Tukur

Department of Public Administration, Faculty of Management and Social Sciences,

Federal University Gusau, Zamfara State

Received: Nov. 20, 2021 Accepted: Jun. 10, 2021 Online published: Jun. 16, 2021

doi:10.5296/jpag.v11i2.15866 URL: https://doi.org/10.5296/jpag.v11i2.15866

\begin{abstract}
This paper investigates the contributions of community stakeholders in the co-production of female child education in Zamfara State, Nigeria. Female child education in Nigeria is associated with some complex issues, like cultural barriers, religious misinterpretations and poverty among rural dwellers, which pose serious challenge for policy makers and public managers. The idea of engaging citizens to make contributions in the design, management and implementation of public polices is called co-production. Studies have revealed that the co-production of public services helped in addressing complex policy problems that cannot be addressed through top-down approach. This paper therefore, adopts co-production as an approach for addressing complexities associated with female child education in Zamfara State, Nigeria. It examines the contributions of community stakeholders in the design, implementation, monitoring and evaluation of universal basic education geared towards improving female child education. The paper purposively selected 100 respondents from some selected local communities. The study similarly adopts a mixed research methods to address research questions. The findings of the study reveal that through social networks, time, will power and personal agency community stakeholders can create awareness, provide learning materials, develop and manage infrastructures to improve female child education. The study concludes that community engagement in the co-production of female child education can improve enrolment, retention of female children in the formal schools. Thus, to enhance female child education, government at all levels should actively engage community
\end{abstract}


stakeholders in all cycles of public policy and public services provision.

Keywords: co-production, public services, community stakeholders, female child education

\section{Introduction}

Co-production of public services and policy is one of the innovative approaches introduced in the management of public sector organisations in a bid to meet the pressing demands of the teeming population. According to Van der Wal (2017) active engagement of citizens in the design, management, delivery and evaluation of public services could help to meet their pressing demands. This enables citizens to decide on the type of public services they want and even contribute to its provision. The idea of co-production is in contrast to the classical model of administration, where citizens have less or no role to play in the design, implementation, delivery and evaluation of public policy and services (Bovaird \& Loeffler, 2012).

The challenges and complexities associated with public services provision in the $21^{\text {st }}$ century, include citizens' demands for more public services amidst fiscal constraints, teeming population, democratic deficit and lack of public trust and support in government trigger the need for public agencies to make a very use of the available resources of other external stakeholders (OECD, 2017; Pestoff, Brandsen, \& Verschuere, 2013).

According to Hughes (2018) one of the innovative changes in the management of public sector is that 'external constituents can and should be managed by the bureaucracies'. He maintains that external stakeholders should not be regarded as threats to bureaucracy, but rather something of interest that may contribute to the success of public agency. These external stakeholders, according to Van der Wal (2017) could be the civil society organisations, local businesses and high-profile citizens who are keenly and passionate to contribute to the development of their own communities.

Therefore, for this study, we build on Van der Wal (2017) to define community stakeholders as all those citizens and group of citizens who supposed to have stake in the way and manner particular community is governed and can make substantial contributions to the development of such community. These individuals and groups are the community-based organisations, religious groups, traditional rulers, expert citizens and women groups who are external stakeholders to the public-sector organizations.

\subsection{Statement of the Research Problem}

The Nigerian Government introduced Universal Basic Education Policy with aim of achieving policy objectives such as (a) ensure unfettered access to nine (9) years access to formal education. That is every child should must have access to uninterrupted six years in primary school providing early childhood development and education, and three years of junior secondary school, (b) provision of free, compulsory and universal education of every Nigerian child of school going age, (c) reducing to a lesser degree, the incidence of prevalent drop-out from formal education system, through improved relevance, quality and efficiency, (d) ensuring the acquisition of appropriate levels of literacy, numeracy, manipulative, communicative and life skills as well as the ethical, moral and civic values needed for laying 
solid foundation for life-long learning $\quad$ (extracted from https://ubeconline.com/about_ubec.php).

The classical model of design, implementation, delivery and evaluation of both public policies remains in use by most of the public-sector organizations in Nigeria (Philip \& Peter, 2013). This indicates the use of inward looking approach that does not allow direct participation of citizens in the design, implementation and evaluation of public polices and services. Thus, improving female child education in Nigeria remains the absolute role of Government through its public agencies. The UBE policy according to Bolaji, Campbell-Evans, and Gray (2017) aimed at overcoming the problem of very low enrolment of children of school age going. The UBE policy serves as the Nigeria's strategy for actualising education for all (EFA), millennium development goals agenda (MDGs) and now sustainable development goals (SDGs). UBE policy have apparently made a provision for the provision of free and compulsory education of female children. All children irrespective of gender or any social class must have access to formal education.

The implementation of UBE policy is through rational bureaucratic arrangements. This involves multiple implementing agencies at Federal, States and Local government areas, with appointed professional officials who are saddled with the responsibility to ensure effective implementation of the UBE policy (Trust, 2014). However, despite concerted efforts by governments at all levels to ensure free and compulsory education for all children of school age going through universal basic education policy; female child education remains a wicked policy issue to be addressed in most part of the local communities of Nigeria. This tally with the findings of UNICEF (2007); UNESCO (2016); British-Council (2014); UNICEF (2007) that Nigeria is among the countries in Sub-Saharan African with highest number of female children out of schools. Similarly, (UNICEF, 2007) reports that there is very low enrolment rate of female children in formal school in northern part of Nigeria.

The report further indicates that the net attendance ratio in Northern Nigeria is at $60.1 \%$, and about $40 \%$ level of non-attendance is among primary school age children. The situation is also the same in our chosen case study which according to Njoku (2018) about 245,560 (two hundred and forty thousand, five hundred and sixty children) are out of school in Zamfara State, and female children constitute the highest number of 132,181 (one hundred and thirty-two thousand, one hundred and eighty-one).This has been attributed to the problem of poverty among parents, lack of awareness which leads to religious misinterpretation and short-term government policies (UNICEF, 2007).

Additionally, it was observed by Kainuwa and Yusuf (2013) that cultural traditions in some local communities of Zamfara State affect female child education. These cultural traditions such as keeping a female child at home for domestic work, street hawking, fear of sexual harassment and insecurity among others. Further, Hartwell (1998) argues in some part of Africa, parents see formal school as a foreign system which they do not have control and authority over curriculum, decision making and staffing. Therefore, they resist any attempts to enrol their female childrem in formal school. Consequently, addressing these complexities facing the female child education may not be done by public sector alone. In response to 
this, Hughes (2018) asserts 'more active forms of outside engagement can provide better overall outcomes'. This outside engagement is in form of co-production of public services with service users or communities. Therefore, this study attempts to address the question of:

i. To what extent community stakeholders can contribute in the co-production of Female Child Education in Zamfara State?

ii. Are the Community Stakeholders actively participating in the co-production of Female Child Education in Zamfara State?

\subsection{Objectives of the Study}

The primary objective of this study is to analyse the extent at which contributions of community stakeholders can be used in the co-production of female child education in Zamfara State, Nigeria. While on the other hand, the secondary objective of the study is to examine the level of community stakeholders' participation in the co-production of female child education in Zamfara State, Nigeria.

\subsection{Significance of the Study}

This study could be very useful to the general body of knowledge and specifically to the theoretical development of co-production of public policy and services. This is because looking at how it presents mixed research methods and a case study approach in a context where there is shortage of studies on co-production public services. Similarly, it could be useful to policy makers and public managers on how best to harness and utilise potentials of external stakeholders (community) in addressing complex policy problems.

\subsection{Limitations and Scope of the Study}

This study only explores the contributions of community stakeholders and has not been able to examine how these stakeholders can work together with public officials in the co-production of female child education. Similarly, due to time and resources constraint, purposive sampling was used to conveniently select the target respondents from three local communities that are considered to have the highest number of female children out of school (Njoku, 2018)

\section{Literature Review and Theoretical Framework}

\subsection{Coproduction of Public Services: Conceptual Clarifications}

The concept of coproduction of public services was popularised by Elinor Ostrom in the early 1970s. Ostrom and her colleague at Indiana University conducted an empirical study on the provision of public services through centralised bureaucracy. The findings of their research revealed that bureaucracy alone cannot satisfy the needs of the teeming population, but active participation of multiple actors (including the citizens) in the public services cycle is an alternative option for effective public service provision.

Like any other concepts in public management and other related disciplines, concept of co-production has been widely defined by various scholars. Nevertheless, there is an attempt to define co-production of public service. Ostrom (1996) defines co-production of public 
services 'as a process through which inputs from individuals who are not in the same organisation are transformed into goods and services'.

In his words, Bovaird (2007) sees co-production as the provision of public services as a 'long term relationships between regular producers of public services, service users and or community members, where all parties make significant contribution of resources to provide public services'.

Ostrom and Bovaird above have all emphasised on the use of external stakeholders (service users or community members) to supplement the efforts of public agency in the provision of public services. But the question to ask in their definitions to what extent these community members can contribute resources and what types of resources are required in the co-production of public services?

In response to the above question, on the extent at which service users or communities can actively participate in the public services cycle, Osborne, Radnor, and Strokosch (2016) and OECD (2011) view co-production of public services as a way in which public sector engage service users, citizens, civil society in the process of designing, planning, management, delivery and evaluation of public policies and services. This explains the stages that the service users or community members can be integrated in the coproduction of public services.

Horne and Shirley (2009) also, argue that co-production of public services is a way of addressing public problems that cannot be address by Government or the communities. Therefore, the need for collaborative approach between public sector and communities is required to maximise capacity. For instance, communities possess social networks, skills, expertise and insights to identify, define the problem and use their energy, time to actively engage in all the problem of solving processes, while, the public sector has funds through budgetary allocations, regulations and professional public managers (Horne \& Shirley, 2009). .

Therefore, it could be appropriate to define co-production of public services as a way of integrating citizens' skills, expertise, insights, energy, time and other resources in the design, implementation, delivery and evaluation of public policy and provision of public services. Thus. In this study we focus on the contributions of community stakeholders in the co-production of female child education.

\subsection{Stages of Co-production of Public Services}

There are different stages or cycles of public services in which citizens who are not part of the mainstream public sector can be integrated to offer their inputs. Pollit et al (2006:5) assert 'public agencies evolve from a classical design-decision-production-evaluation cycle to an involvement of stakeholders in general and citizens in particular at each and every stage. These stages or forms of co-production according to Pollit et al (2006) and Governance International (2017) are:

\subsubsection{Co-Design}

Traditionally, public policy and services are formulated and designed solely by the 
bureaucracy where citizens serve as mere passive recipients of public services without offering any inputs on how to formulate public policy or provide public services. In contrast to this, co-design approach integrates services users and other external stakeholders in the formulation of public policy and design of public services.

The rationale behind co-design according to Evans and Terrey (2016) is to harness the skills, insights and expertise of citizens in designing public policy or public service that can best work for the people. They maintain that to solve critical public problems, public policies and or public services need to be created jointly with citizens and other stakeholders. Under this, citizens can voice out their preferences on what constitute the content of public services that best suit their context. Participatory budgeting is a good example, where citizens can participate in the annual budget process by proposing budget priorities and even voting on budget items to determine their preferences (OECD, 2011).

\subsubsection{Co-Delivery}

This refers to the engagement of citizens or stakeholders at the delivery stage of public service. In this arrangement, citizens or service users are trained to deliver their own services. Loeffler and Bovaird (2016) present a case study on how community health trainers in Manchester, UK enable positive lifestyle change. This programme was launched in 2006 by National Health Service (NHS) UK. The NHS trained local people to develop their own skills on how to live a healthier life by strengthening prevention of diseases in vulnerable and marginalised communities. This strengthens the community in maintaining a good lifestyle that could improve their healthy living.

\subsubsection{Co-Management}

In this approach, third sector/civil society organisations produce public services in collaboration with state agencies. That is a situation where public agency partners with civil society organisation to provide public services (Pestoff \& Brandsen, 2013).

\subsubsection{Co-Evaluation}

This is another form of coproduction where citizens assess the quality of public services delivered to them. For example, check my school initiative was launched by Department of Education in Philippines in which citizens inspect and report the situation of local schools to the concerned authority(Shkabatur, 2014)

\subsection{Review of the Relevant Studies on co-Production of Public Services}

A qualitative study conducted by Van Geertsom, Lemaire, and Loeffler (2017) explains how co-production was used to meet the needs of people living in poverty and social exclusion in Belgium. The study reveals that government efforts to provide public services to vulnerable people have not been successful due to non-involvement of the target group, and these groups of people have the expertise and experience to support the provision of their own services.

In response to this social problem, a co-productive project tagged 'Expert by Experience' was launched to integrate some selected vulnerable people in the design and delivery of their own 
services with a view of harnessing their experience and insights on how best to provide services that best meet their demands.

Among the roles played by these experts by experience are assisting other citizens in filling forms to seek for help and supports from the government. Further, Van Geerstorm et al reveal co-productive approach has streamlined interface between officials and the service users, and it creates better understanding of the problems facing the vulnerable people and helps to meet the needs of the affected citizens. According to Bardach and Patashnik (2016) working with communities or service users helps to clearly defined policy problem and discover possible ways of addressing the problem.

Van Geerstom et al study above, is relevant to our study because they explore some core benefits of co-production such as creating an interface for working relationship between public officials and the target beneficiaries of public services, skills and expertise of the service users involved in the co-production. However, while it remains relevant to our study, it is limited to only particular group of vulnerable citizens. Thus, our study went further to investigate how collective efforts of community stakeholders can be used to co-produce female child education using a mixed research approach.

Another qualitative study by Jacobsen (2015) explores ways of making parents to know their role in improving reading capacity of their children, and how the school officials can mutually work with parents to achieve a common goal of improving reading capacity of school pupils. The parents of the affected students were invited by the school officials to spare fifteen minutes daily in assisting their kids learning. On their own part, the school officials provide the invited parents with some instructional materials such as books and guidelines on how to create a shared reading with their kids. However, the idea of engaging parents may be inadequate enough to provide education for all. Because some parents may display some problems such as absenteeism during parents-teachers meeting, lack of proper support and guidance to their children, and above all, poverty and ignorance level of some parents could directly or indirectly hinder effort to improve children education.

In her study, Shkabatur (2014) conducted a qualitative case study on citizen's monitoring and evaluation of public education in Philippines tagged 'check my school initiative'. The study reveals that agency for public education planned to increase community awareness and involvement of parents, community members, local businesses and youth groups in the provision of education through monitoring the conditions of public schools and in collaborative problem solving. She maintains, some of the roles played by the communities include, providing feedbacks on the school budgetary allocations, enrolment, quality and quantity of teachers, availability of books, classrooms etc. The initiative also aims at raising issues of concerns through comments via website of the agency for public education.

The engaged community members and socially active individuals established contacts with the schools and education authority to collect data on school activities through frequent visits to schools in order to generate new data and relate it with the official data with a view of detecting any difference. This helps to report problems such as inadequate classrooms, lack of textbooks and other facilities that require urgent attention of the education department. 


\section{Macrothink}

Journal of Public Administration and Governance ISSN 2161-7104

2021, Vol. 11, No. 2

Co-production makes communities to have access to officials data reporting public school activities and participates actively in monitoring and evaluation of public education in Philippines. It also helps to harness local networks of civil society groups and socially active individuals to work together towards improving public education in the Philippines.

The findings of Shkabatur (2014) study strongly indicate that community stakeholders are more likely to participate in the co-production of education than just the parents alone, especially when empowered by the public agency. Thus, our study builds on this to investigate the potentials of community stakeholders in the co-production of female child education with more emphasis on broader part of co-production against the co-evaluation stage used by (Shkabatur, 2014).

Another study by Kanau and Haruna (2013) uses historical approach to suggest ways of promoting community contributions to education in Nigeria. According to their study, communities were having stake in upbringing, training and education of their children through provision of learning and reading materials, class rooms and shelter for the teachers. But these contributions of the communities have not been considered by the government as what could improve education services. This correlates with the work of Ostrom (1996) which found out that communities in Nigeria used to have a stake in the decision making affecting transfer and retention of teachers and even provide shelter and food for the serving teachers. However, top-down decision making and frequent change of governments through military coups thwarted community engagement in the co-production of education in Nigeria.

The study by Kanau and Haruna is quite relevant to our study since it provides historical antecedents of community contributions in the co-production of educational services, but the historical approach it used may not be enough to study community contribution in the provision of education services. Thus, the need for empirical study in this area becomes important, and therefore our study is designed to empirically study how these contributions of community members can help to co-produce female child in Nigeria.

\subsection{Theoretical Framework}

Government and Citizens resources contribution framework coined by Horne and Shirley (2009) is employed to guide this study. As indicated below in figure 2.4.1. This framework specifies the type of resources that both the external stakeholders and government can contribute in the co-production of public services. 
2.4.1 A Framework for Citizens and Government's Resource Contributions

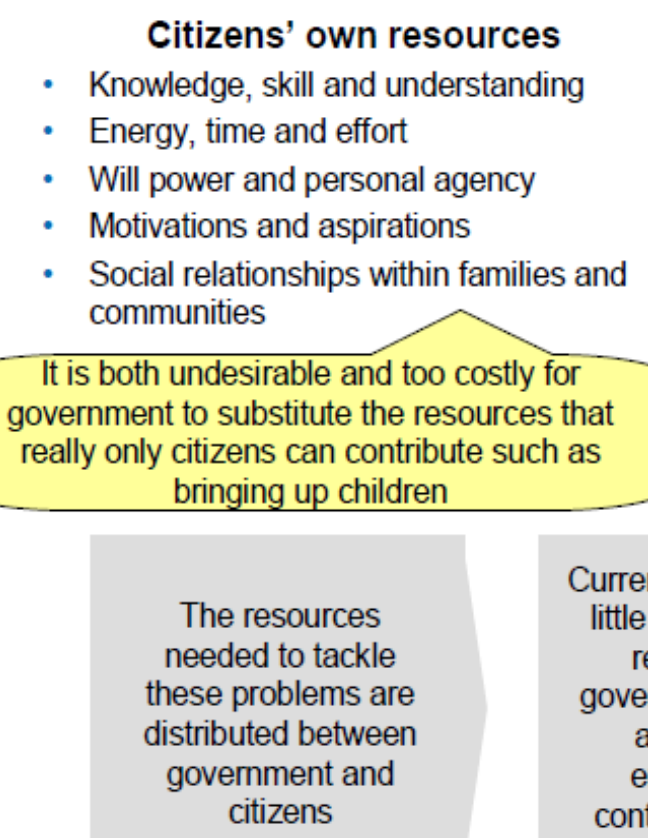

ces

Knowledge, skill and understanding

- Energy, time and effort

- Will power and personal agency

Motivations and aspirations

Social relationships within families and communities

The resources

needed to tackle

these problems are

distributed between citizens

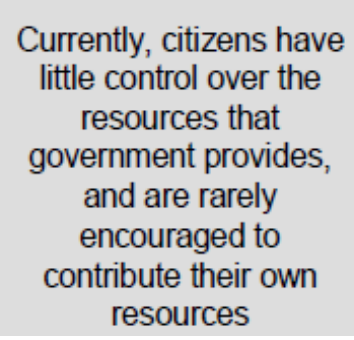

Government's resources

- Money

- Rules and regulation

- Expert knowledge and skills

- Energy, time and labour of public services professionals

- Leadership, expectations and aspirations

Figure 2.4.1. Source: Horne and Shirley (2009:9)

The above framework explains the type of resources that government, citizens and or community stakeholders can contribute in the co-production of public services. For instance, public agency uses its internal structure and resources to relate with community stakeholders. As indicated above in figure 2.4.1, government has the money, rules and regulations, expert knowledge and skills, energy time and labour of public service professionals and leadership, while on the other hand, citizens (the community stakeholders) have knowledge and understanding of community problems, energy, time and efforts (to work actively with the public officials), will power, personal agency, motivations, aspirations, social relationships within families and communities (to convince, gain support, persuade and influence other members of the community) to participate in the co-production of public services.

However, according to Sullivan and Skelcher (2017) 'lack of time and money can some time limit individual or community involvement in collaboration with public agency', and social inequality may likely affect participation of some minority groups of individuals. But, yet to a certain degree, Alford (2009) asserts that government can develop citizens capacity by given them incentives and training programmes to boost their motivation and capacity. Thus, government can empower community members (including the marginalised members) to co-produce public services.

\section{Methodology}

A case study approach was used to carefully study how community stakeholders in some selected communities of Zamfara can contribute in the co-production of female child education. The case study approach helps our study to have an in-depth understanding of 
some phenomena within the selected geographical area.

\subsection{Data Collection}

In response to the question of to what extent community stakeholders can contribute in the co-production of female child education? This study generates both quantitative and qualitative data. The quantitative data was generated through semi-structured survey instrument. The semi structured survey is flexible as it gives respondent an opportunity to express his independent views, and the structured interview instrument also gives the researcher an avenue for controlling the conversations with the respondents to avoid deviation from the main theme of the interview.

The qualitative data provides an explanatory insight of the data generated through semi-structured survey. However, the rationale for using mixed research method is to have a balanced research method that have the strength to offset weaknesses of both quantitative and qualitative research method.

\subsection{Sample and Sampling Technique}

The study uses purposive sampling technique to conveniently select the sample population of 100 respondents. These respondents were drawn from religious leaders, traditional leaders, community youth organisations and some influential members of the society who are considered to have the potentials and the enthusiasm of supporting co-production of female child education. For this reason, the following communities were selected due to the higher number of female children out of school as shown in the table 3.2:

\begin{tabular}{|r|l|c|}
\hline S/N & Local Government Area & Number of female children out of school \\
\hline 1. & Bukkuyum & $\mathbf{5 2 , 7 1 5}$ \\
\hline 2. & Maradun & $\mathbf{3 4 , 9 8 0}$ \\
\hline 3. & Zurmi & $\mathbf{4 4 , 4 8 6}$ \\
\hline 4. & TOTAL & $\mathbf{1 3 2 , 1 8 1}$ \\
\hline
\end{tabular}

Source: UNICEF (In Daily Trust, 2018).

Table 3.2 shows that one hundred and thirty-two thousand, one hundred and eighty-one female children are out of school in three local communities of Zamfara State, Nigeria.

\subsection{Data Analysis}

As stated earlier, we used quantitative and qualitative data. Quantitative data was presented in descriptive statistical form using graphs (pie chart) to summarise the type of contributions community can offer in the co-production of female child education.

On the other hand, the interviews results were analyses through thematic method. This is 
done through identification of the key themes relevant to this study. However, the data transcription which is commonly associated with the thematic method of data analysis is time consuming and has no standard way of conducting. In contrast, our study does not involve large amount of qualitative data, so, the themes were easily captured and analysed.

\section{Discussion of Results}

The main objective of this paper is to examine the contributions of community stakeholders in the co-production of female child education in Zamfara State. In this sense, the Government and Citizens resources contribution framework of Horne and Shirley (2009:9) is used to guide our study. This framework points out social networks, energy, time, efforts, will power and personal agency as what constitutes citizens (community stakeholders) resources in the co-production of public services, while the Government has funds, regulations, professional public servants among others. As stated earlier, our focus is on the community stakeholders, thus, the level at which community stakeholders participate in the co-production of female child education and the type of resources at their disposal were examined below.

\subsection{Survey Administration}

Total of one hundred surveys were distributed and only 57 were successfully completed and returned. Table 4.1 below gives the description of number of questionnaire distributed, returned, completed and not returned.

Table 4.1.

\begin{tabular}{|r|c|c|c|c|}
\hline S/N & Local Government Area & Distributed & Returned & Not Returned \\
& & & completed & \\
\hline & Bukkuyum & 40 & 21 & 19 \\
\hline 1. & Maradun & 30 & 19 & 11 \\
\hline 3. & Zurmi & 30 & 17 & 13 \\
\hline
\end{tabular}

Source: Researcher's Survey, 2018.

The above table shows that Bukkuyum Local Government returned and completed twenty-one questionnaire (21) out of forty (40) administered. Maradun has total of 19 questionnaires completed and returned out of the 30 distributed, while Zurmi has total of 30 surveys distributed and only 17 were successfully completed and returned. 
4.1.1 Level of Community Stakeholders Participation in the co-production of Female Child Education

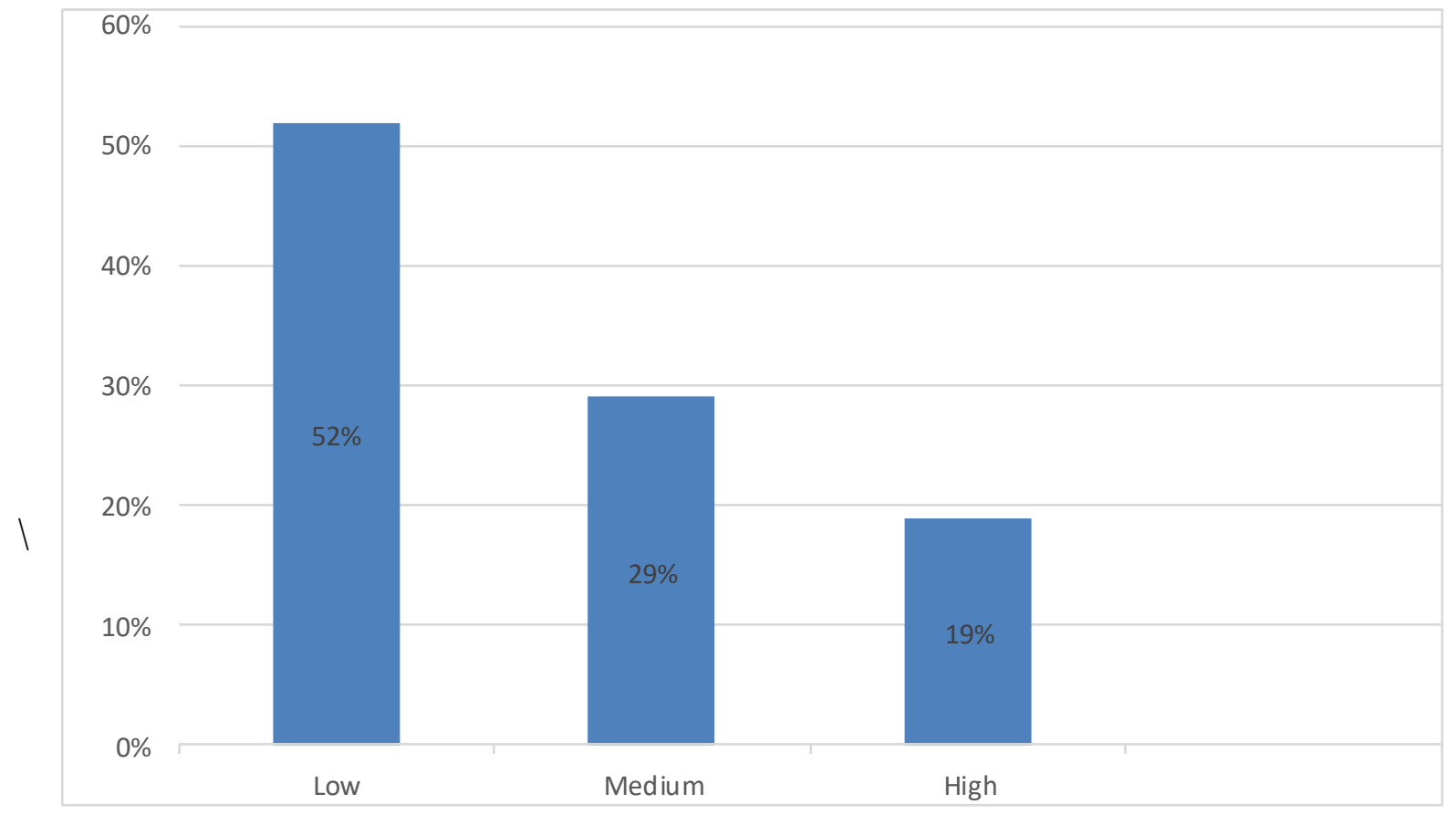

Figure 4.1.1

Source: Researcher's Survey, 2018.

Figure 4.1.1 above shows that community stakeholders have low participation with (52\%) in the co-production of female child education. Community stakeholders participate in the co-production of female child education at medium level of $29 \%$, while only $19 \%$ of the respondents opined that community participation in the co-production of female child education is high.

4.1.2 The Extent at which time, efforts, will power and personal agency of community stakeholders can improve Female Child Education

The respondents were asked on what they can offer as contributions in the co-production of female child education. The responses are presented below: 


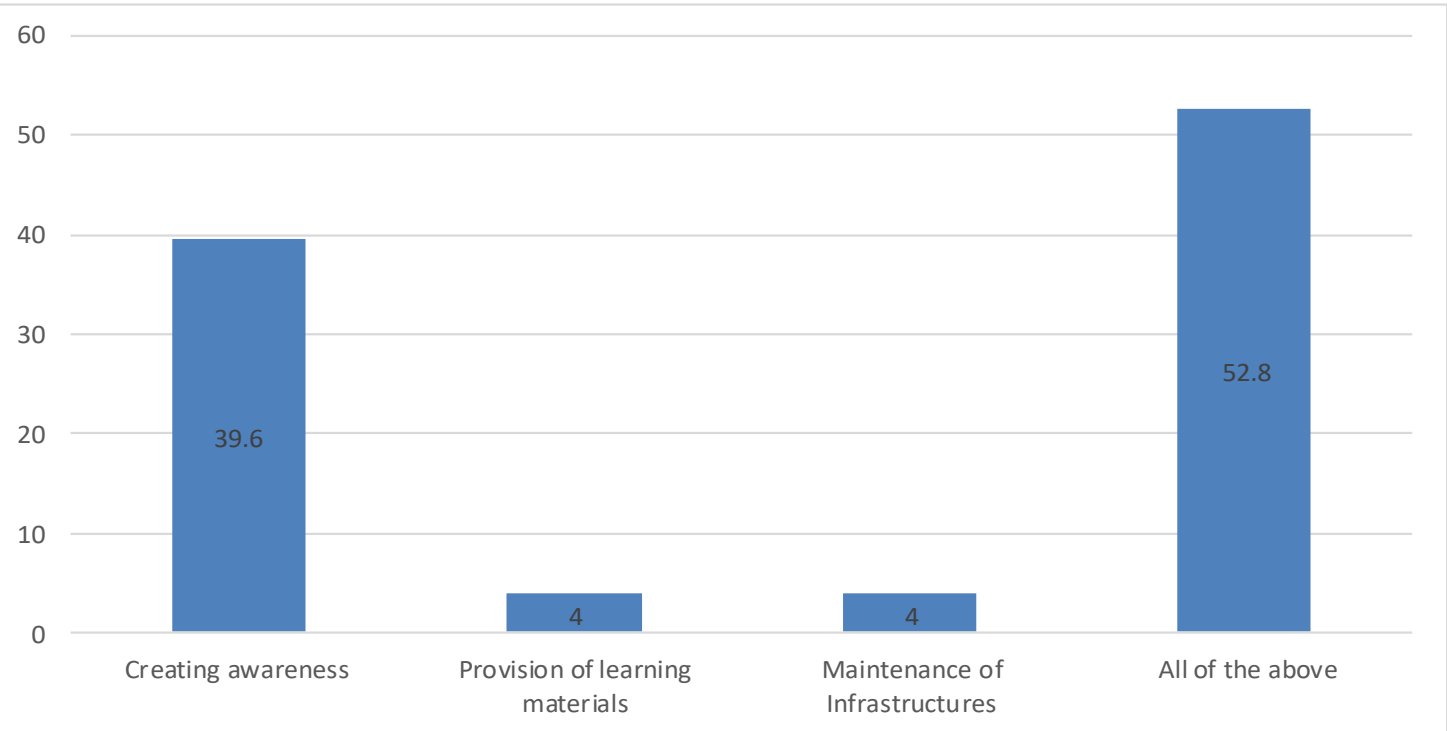

Figure 4.1.2. Source: Researcher's Survey, 2018

Figure 4.1.2, above shows that $39.6 \%$ of the respondents agreed to use their time and will power create awareness on the importance of female child education to other community members who see female child education contrary to their norms and values. While $4 \%$ of the respondents choose to contribute teaching and learning materials. While, $4 \%$ of the respondents choose to assist in the maintenance of school infrastructures. On the other hand, $52.8 \%$ of the respondents demonstrate their willingness to contribute all of the above listed roles.

4.1.3 To what extent co-production can improve female child education?

Respondents were asked on how co-production can improve female child education?

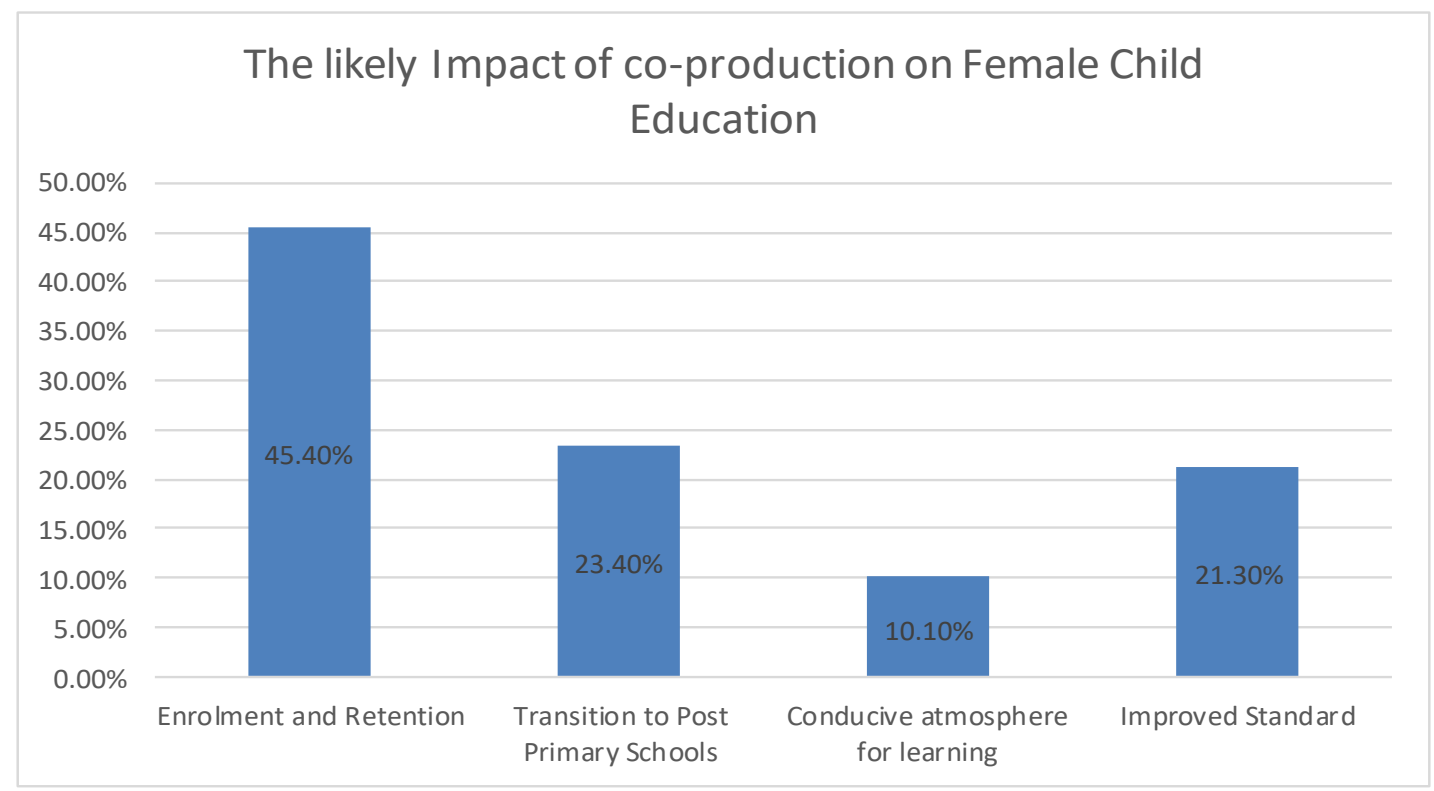

Figure 4.1.3.

Source: Researcher's Survey, 2018. 


\section{Mll Macrothink}

Journal of Public Administration and Governance ISSN 2161-7104 2021, Vol. 11, No. 2

From the figure 4.1 .3 above, $45.4 \%$ of the responses show that community co-production of female child education can increase enrolment and retention of female children in schools. Only $23.40 \%$ opined it can impact on transition to post primary schools. The $10.10 \%$ of the respondents believe community co-production of female child education can result to having a conducive environment for effective teaching and learning. On the other hand, 21.3\% opined community co-production can improve the moral standard for both pupils and the teachers.

\subsection{Interview Results}

The structured interviews were conducted through phone calls as a follow up to the responses generated from the survey. The survey was semi-structured in which respondents were asked to indicate their preferences by dropping their contact details on whether to be interviewed or not. The total number of five respondents were selected and only three were successfully interviewed as follows:

\subsubsection{The Effect of Social Networks on Female Child Education}

Respondent Number 1: Religious leaders are very influential in determining what society can do and undo, thus they can be used to create awareness on mitigating misconceptions and misinterpretations of religious scriptures on female child education.

Respondent Number 2: Our communities are interconnected and interdependent with one another, so creating public awareness by community members on the importance of female child education within families, friends and neighbours could easily be possible.

The responses above show how cultural and religious misconception can be reduced through social network of community stakeholders such as religious groups, neighbours, families and friends. This tallies with the used framework coined by Horne and Shirley (2009) argue social relationship as one of the resources the citizens possess to trigger change in their respective communities.

4.2.2 How community members can use their time, energy and personal agency to co-produce female child education?

Respondent Number 1: Unemployed youth with teaching profession can volunteer to cover shortage of teaching staff'. He maintains, community members can also contribute in developing and managing school infrastructures.

Respondent Number 2: Engaging community stakeholders to offer their inputs in the design and implementation of female child education could likely help to design policy that reflect cultural and religious values of the community.

The interview results show that community stakeholders can offer their time, energy and personal agency. As indicated above, youth groups can offer voluntary teaching assistant to cover shortage of teaching staff in some remotest areas. This could make community members to believe that formal schools are not alien to them as found out by Hartwell (1998) due to engagement of their sons and daughters in teaching activities. In addition to this, other 
stakeholders (especially the religious and community leaders) could play an active role in policy design and the day to day management and evaluation of school affairs to ensure compliance to the agreed policy objectives.

\section{Major Findings}

Below are some of the major findings of this study:

\subsection{Social Network}

It was found out that through communal or social networks community can boost enrolment, retention of female children and their transition to post primary schools. This is looking at the interconnectedness of families, friends and neighbourhood which could facilitate public awareness on the importance of female child education in Zamfara State, Nigeria. This is in line with the citizens and Government resources contribution framework by Horney and Shirley (2009:9) used in this study.

\subsection{Will Power, Energy, Time and Personal Agency}

It was found that community stakeholders have the will power, energy, time and personal agency to contribute in the co-production of female child education in Zamfara State. As indicated in the survey results, community stakeholders can provide learning and reading materials and actively participated in the development and management of school infrastructures. Similarly, it was found out that, youth with requisite teaching experiences can offer teaching assistance in some places where there is shortage of teaching staff.

\subsection{Ability to Make Inputs in Policy Design and Implementation}

It was found out in the interview results that, inclusion of community stakeholders to offer their inputs in the design and implementation of female child education (UBE policy) that reflect religious and cultural values of community members could help in boosting female child education. This could make community members feel that female child education is not a foreign invention and or against their norms and values (Hartwell, 1998).

5.3.1 Community participation in the co-production of female child education: It was found out that there is low participation of community members in the co-production of female child education. This may be connected to the findings of Ostrom (1996) that the centralised and rigid structure of Nigerian public agencies thwarts community co-production of education services.

\section{Conclusion}

Co-production of public services is one of the innovative approaches in public management geared towards addressing complex policy problems that cannot be addressed by either government or the citizens. This facilitates the use of collaborative approach where each collaborator has something to offer in addressing public problem. It is in this sense that, this paper analyses the contributions of community stakeholders in the co-production of female child education in Zamfara State. It shows that female child education can be improved by engaging community stakeholders to offer their inputs in the design and implementation of 
female child education (UBE policy).

The increased rate of female children out of school may be connected to non-engagement of communities in the policy process. These communities have the skills, insights, social networks, energy and time to improve enrolment and retention of female children in schools and even ensure transition to post primary schools. Similarly, these stakeholders can offer contributions in developing and managing school infrastructures as well as monitoring and evaluation of school daily affairs to ensure compliance to the agreed policy objectives. This paper would hope to have added value to the existing body of scholarship on co-production of public services looking at how it examines contributions of stakeholders in the co-production of female child education, which many studies on co-production have not focused on. It would also hope to serve as guide for public managers and policy makers on how to harness the potentials of citizens as contribution in policy making and public service provision.

\section{Recommendations}

This paper proffers the following recommendations for practical and theoretical implications:

i. It is recommended that, since community can play a vital role in creating public awareness on the importance of female child education, public agencies responsible for formulation and implementation of female child education policy should consider the use of community stakeholders in policy cycles. This could help in mitigating religious misinterpretations on a claim that female child education is against religious teachings and possibly increase enrolment, retention and transition of female children from primary to post primary schools.

ii. Lack trust between government and rural dwellers can be mitigated if not addressed when community stakeholders are carried along in the formulation and implementation of UBE policy.

iii. For theoretical implications, other studies should study interconnectedness between public officials and these community stakeholders using any of stratified or random sampling technique to reflect the overall population of the chosen case studies.

\section{Acknowledgment}

The authors acknowledge the support of Tertiary Education Trust Fund, Nigeria for providing funds for this research project under Institution Based Research (TETFUND/DRSS/UNI/GUSAU/RP/VOL 1)

\section{References}

Alford, J. (2009). Engaging public sector clients: From service-delivery to co-production: Springer. https://doi.org/10.1057/9780230235816

Bardach, E., \& Patashnik, E. M. (2016). Practical Guide for Policy Analysis: The Eightfold Path to More Effective. 
Bolaji, S. D., Campbell-Evans, G., \& Gray, J. R. (2017). The Perils of Bureaucratic Complexity: Education for All in Nigeria. International Journal of Educational Administration and Policy Studies, 9(1), 1-9. https://doi.org/10.5897/IJEAPS2016.0480

Bovaird, T. (2007). Beyond engagement and participation: User and community coproduction of public services. Public administration review, 67(5), 846-860. https://doi.org/10.1111/j.1540-6210.2007.00773.x

Bovaird, T., \& Loeffler, E. (2012). From engagement to co-production: The contribution of users and communities to outcomes and public value. Voluntas: International Journal of $\begin{array}{llll}\text { Voluntary and Nonprofit } \quad \text { Organizations, } & \text { 23(4), }\end{array}$ https://doi.org/10.1007/s11266-012-9309-6

British-Council. (2014). Girl child education in Nigeria: Issues, influencers and actions. A Report by

$\begin{array}{llll}\text { British } & \text { council. } & \text { Retrieved from }\end{array}$ https://www.britishcouncil.org/sites/default/files/british-council-girls-education-nigeria-repor t.pdf

Evans, M., \& Terrey, N. (2016). Co-design with citizens and stakeholders. Evidence-based policy making in the social sciences: Methods that matter, 243-262. https://doi.org/10.2307/j.ctt1t89d4k.20

Hartwell, A. (1998). Enhancing Girls' Education through Community Schools. USAID Girls' and Women's Education Activity. Portfolio of Possibilities for Girls' Education. May.

Horne, M., \& Shirley, T. (2009). Co-production in public services: a new partnership with citizens. London: Cabinet Office.

Hughes, O. E. (2018). Public Management and Administration: An Introduction (Fifth ed.): Macmillan International. https://doi.org/10.1057/978-1-137-56010-0_4

Jacobsen, N. H., M. (2015). Read with Me': How teachers in Aarhus support parents to improve their children reading skills. . UK. Retrieved from http://www.govint.org/good-practice/case-studies/read-with-me-how-teachers-in-aarhus-supp ort-parents-to-improve-their-childrens-reading-skills/

Kainuwa, A., \& Yusuf, N. B. M. (2013). Cultural traditions and practices of the parents as barriers to girl-child education in Zamfara State Nigeria. International journal of scientific and research publication, 3(11), 1-8.

Kanau, A. A., \& Haruna, M. (2013). Towards Promoting Community Participation in Education in Nigeria. Academic Journal of Interdisciplinary Studies, 2(7), 131.

Loeffler, E., \& Bovaird, T. (2016). User and community co-production of public services: What does the evidence tell us? International Journal of Public Administration, 39(13), 1006-1019. https://doi.org/10.1080/01900692.2016.1250559 
Njoku, G. (2018). Cash transfers help children enrol in school in Zamfara State. UNICEF

OECD. (2011). Together for Better Public Services: Partnering with Citizens and Civil Society.

OECD. (2017). Trust and Public Policy.

Osborne, S. P., Radnor, Z., \& Strokosch, K. (2016). Co-production and the co-creation of value in public services: a suitable case for treatment? Public Management Review, 18(5), 639-653. https://doi.org/10.1080/14719037.2015.1111927

Ostrom, E. (1996). Crossing the great divide: coproduction, synergy, and development. World development, 24(6), 1073-1087. https://doi.org/10.1016/0305-750X(96)00023-X

Pestoff, V., \& Brandsen, T. (2013). Co-production: the third sector and the delivery of public services: Routledge. https://doi.org/10.4324/9781315878430

Pestoff, V., Brandsen, T., \& Verschuere, B. (2013). New public governance, the third sector, and co-production: Routledge. https://doi.org/10.4324/9780203152294

Philip, D., \& Peter, D. (2013). Public policy making and implementation in Nigeria: Connecting the Nexus. Public Policy, 3(6).

Shkabatur, J. (2014). Check My School: A case study on citizens' monitoring of the education sector in the Philippines. World Bank. https://doi.org/10.1596/978-1-4648-0191-4_ch6

Sullivan, H., \& Skelcher, C. (2017). Working across boundaries: collaboration in public services: Macmillan International Higher Education.

Trust, D. (2014). Fifteen (15) years after, has UBE achieved its objectives? Retrieved from https://www.dailytrust.com.ng/daily/education/35820-15-years-after-has-ube-achieved-its-obj ectives

UNESCO. (2016). Out-of-school children of primary school age between 2008 and 2013 AfricaN Office UNESCO Retrieved from http://uis.unesco.org/africa-indicator/edu_africa-ofs-ofst-11.

UNICEF. (2007). Information Sheet on Girl Child Education: Nigeria Country office. Retrieved from https://www.unicef.org/wcaro/WCARO_Nigeria_Factsheets_GirlsEducation.pdf.

Van der Wal, Z. (2017). The 21st century public manager: Macmillan International Higher Education. https://doi.org/10.1057/978-1-137-50744-0

Van Geertsom, J., Lemaire, F., \& Loeffler, E. (2017). How 'experts by experience in poverty and social exclusion'improve access and the quality of public services in Belgium. Governance International Case Study. Birmingham: Governance Interna-tional. http://www. govint. org/good-practice/case-studies/co-production-with-exp erts-by-experience-in-poverty-and-social-exclusion-in-belgium. 


\section{Copyright Disclaimer}

Copyright for this article is retained by the author(s), with first publication rights granted to the journal.

This is an open-access article distributed under the terms and conditions of the Creative Commons Attribution license (http://creativecommons.org/licenses/by/4.0/). 